\title{
The Minimal Conditions for a Financial Crisis: A Multiregional Intertemporal CGE Model of the Asian Crisis
}

\author{
IRMA ADELMAN * \\ University of California at Berkeley, Berkeley, USA
}

and

\author{
ERINC YELDAN \\ Bilkent University, Ankara, Turkey
}

\begin{abstract}
Summary. - The globalization of world capitalism constrains the ability of the developmental state to pursue an independent industrialization and foreign trade strategy. We use an intertemporal, multiregion CGE model, to study the fundamental reasons for a financial crisis. We find that we can create a realistic crisis in the Asia region when capital markets are open and there is an unexpected rise in the risk premium of the Asia region. When capital markets are closed and the state retains all its policy instruments, the Asia region not only avoids a crisis but increases its rate of growth. (C) 2000 Published by Elsevier Science Ltd. All rights reserved.
\end{abstract}

\section{INTRODUCTION}

The Asian financial crisis has had a profound impact on the global economy. Global growth have been slower; risks has been higher; and the international flows of capital have been severely disrupted. The crisis has also revealed the extent to which the globalization of world capitalism constrains the capacity of a developmental state to implement an independent strategy of industrialization and foreign trade.

Our reading of the actual Asian financial crisis is that it cannot be explained by fiscal or monetary excesses. Nor can it be explained by a single factor. Rather, in practice, a multitude of factors, both domestic and international, contributed significantly to the crisis. On the domestic side, there were faulty policies leading up to the crisis; an incorrect mix of government intervention with market forces in the governance and operation of both the financial and corporate sectors; major instances of corruption; a lack of leadership commitment to development which allowed political considerations and, in some Asian countries, personal greed to dominate government economic decision.
The incorrect policies included maintaining an appreciating exchange rate, allowing wages to rise faster than productivity (especially in Korea), and maintaining a risk-adjusted real interest rate that was substantially higher than the world real rate. The combination of these policies led to a progressive loss of competitiveness on world markets and, ultimately, a negative balance of trade.

The inappropriate mix of government and market forces consisted of: combining government-mandated, corruption-motivated loans to mismanaged business groups with a lack of banking regulation and transparency; combining a high interest rate on loans with too low a spread between deposit rates and loan rates (especially in Korea); postponing the necessary

\footnotetext{
* A previous version of this paper was presented at a GTAP conference in Odensee Denmark, June 1999 and at the Third International Conference by METU in Ankara, September 1999. We are indebted to A. Salih, W. Mc Kibbin, N. Alemdar, K. Boratav, X. Diao and to colleagues at Berkeley and Bilkent for their helpful comments. None of them bears any responsibility for the policy implications and views expressed in this paper.
} 
adjustments of exchange rates to the appreciation of the domestic currencies induced by the Japanese recession; having an incorrect mix of regulation and liberalization of the financial system, characterized by very little prudential regulation of banks and corporations combined with greater freedom in borrowing and lending, especially abroad; and removing controls on financial markets combined with setting high domestic interest rates and maintaining domestic financial repression.

On the international side, the actual crisis was due to institutional deficiencies in the architecture of the global economy's financial system to which the region had become vulnerable as a result of the liberalization of its financial markets. Most contributors to this issue agree that the short-term global financial markets are too large, too volatile, too perfect, and too subject to herd psychology.

Finally, one might also view the crisis as the result of a fundamental incompatibility between an independent national financial policy with complete financial liberalization. Two of the major policy mistakes of Asian countries were trying to have an exchange rate policy which was out of alignment with purchasing power parity and an interest rate which was out of alignment with world interest rates, while having largely liberalized capital flows. The Asian crisis demonstrated graphically that this is an economic impossibility. The crisis also revealed how unforgiving global markets are to mistakes in economic policy and to institutional inadequacies within countries and how severe the penalties for mistakes are.

Which of these multitude of factors were essential to the crisis? This is the question we attempt to answer in this paper. To disentangle the fundamental forces from the merely contributory ones requires a modeling approach. We utilize a multi-region, intertemporally consistent computable general equilibrium (CGE) model to study this issue. The global world economy is disaggregated into three regions (developed, underdeveloped, and the crisis-hit Asian economies), each of which produces output in four sectors (agriculture, consumer manufacturing, producer manufacturing, and services). The model is fully Walrasian. It has perfect markets with intertemporally rational, preference-optimizing consumers and profit-maximizing, competitive producers in both factor and commodity markets. The model also accommodates financial flows, in the form of domestic and foreign bonds, that respond to interest rate differentials.

The model is useful because it permits us to isolate analytically the conditions leading to a financial crisis. The model can generate a financial crisis without government intervention, irrational expectations, imperfect markets, lack of information, lack of transparency or corruption. We shall see that we are able to create a crisis, with roughly the same impact on growth as experienced by East Asia in actuality, in a full Arrow-Debreu setup with Ramsey-type forward-looking, intertemporally optimizing rational agents and no government intervention or International Monetary Fund (IMF) conditionality.

Experiments with the model indicate that the fundamental culprit is the liberalization of capital inflows and outflows. We can generate a crisis merely by adding foreign borrowing and lending to the traditional fully neoclassical real model. In contrast, by closing the domestic economy to international capital flows we can avoid a crisis. We model private foreign borrowing as a function of "financial arbitrage," i.e. of the differential between the net, risk adjusted, real return on foreign exchange in domestic and world markets. Increased foreign indebtedness leads to increased financial fragility of the region. The fragility is modeled by a risk-generator function which sets the region's risk premium proportional to the ratio of its foreign deficit to its aggregate GDP. The financial crisis arises when there is a sudden, unexpected, but not irrational, increase in the proportionality parameter linking the deficitratio to the region's risk premium in the riskgenerator function.

The paper is organized as follows: In section 2, we provide a brief overview of theory and experience with financial liberalization. We introduce the salient features of our computable generalized equilibrium (CGE) model in section 3. Section 4 presents a numerical general equilibrium analysis of the root-causes and consequences of the crisis. We draw the policy implications from a development-economics perspective in the final section.

\section{FINANCIAL LIBERALIZATION: THEORY AND REALITY}

The proponents of financial liberalization rely on standard economic theory to deduce the proposition that, in a world of freely mobile 
capital, funds would flow from high-saving to low-saving countries, thereby equalizing interest rates globally and enabling countries to escape the size constraints upon their domestic asset markets. This hypothesis leads to the expectation that funds would flow from the capital-abundant "North" to the capital-scarce "South," promoting not only increased global efficiency, but also improved global equity.

This benign view of the implications of international capital-mobility has been challenged significantly by events in the last two decades. The findings from many empirical case studies of recent financial crises (especially, the Mexican, Turkish and East Asian ones) indicate that the expected beneficial effects of capital inflows are overshadowed by the adverse impacts of excessive capital-market, stock-market and exchange-rate volatility. The effects of volatility had been generally ignored in traditional global capital market models.

Furthermore, in a world of volatile exchange rates, the theoretically-predicted global equalization of interest rates need not take place. In such a world the free mobility of international capital flows does not suffice to equalize real domestic interest rates on loans that are denominated in different currencies. One can distinguish between two types of interest rate differentials: covered and uncovered (see, e.g., Frankel, 1991). Denoting the domestic and foreign interest rates by $r$ and $r^{*}$, respectively; and the forward premium on foreign currency by $\Delta \epsilon$, covered interest rate parity holds when $r-r^{*}=\Delta \epsilon$. By contrast, uncovered interest parity holds if the interest rate differential is equated to the expected rate of depreciation of the currency: $r-r^{*}=E \Delta \epsilon$. This latter condition requires covered interest parity plus the absence of any exchange-risk premium. There is now firm evidence that while covered interest parity is satisfied, for both developed economies and for those developing countries which have liberalized their capital markets, uncovered interest parity is not satisfied. The persistent divergence between real rates of return across countries has been documented by Frankel (1991, 1992, 1993), Marston (1997), Halwood and MacDonald (1994), Blecker (1998) and Eatwell (1996). As noted by Frankel (1991, p. 252)

a currency premium remains, consisting of an exchange risk premium plus expected real currency depreciation. This means that, even with the equalization of covered interest rates, large differentials in real interest rates remain (emphasis original).
The currency premiums, with the resultant differentials in real rates of return across countries, will provide one of the main dynamic adjustment mechanisms in our model.

Finally, it is also worth noting that while the postfinancial liberalization global economy is characterized by very large gross capital flows, it has generated rather small net transfers. As indicated by Tobin (this issue), as of 1995, net capital flows from developed to underdeveloped countries were only $\$ 150$ billions per annum, while the daily volume of, mostly speculative, foreign exchange transactions reached \$1.5 trillions. The gross volume of international capital flows across national boundaries is far in excess of the financing needs of the sum of commodity trade flows and investments in physical capital, and is mostly driven by speculative considerations of risk hedging and currency speculation. ${ }^{1}$

\section{THE MODEL}

The model is based on neoclassical growth theory. It is a global intertemporal computable general equilibrium (CGE) model with a multiregion specification. We distinguish three regions (Underdeveloped POOR, Developed $R I C H$, and Crisis-Hit Asian region, CHAR). Each region produces four types of goods in the same number of production-sectors.

The general characteristics of this model are well known: ${ }^{2}$ Infinitely-lived households consume home produced and imported goods so as to maximize an additively separable, intertemporal utility function. Household income is either consumed or saved. Savings take the form of equity in domestic firms or in foreign bonds. The private agents in each region have free access to an open, unregulated, world capital market at a given world interest rate.

One distinguishing feature of the current model is its treatment of the determination of the interest rate at the regional level. ${ }^{3}$ The domestic rate of interest differs from the world interest rate by a risk premium. The risk premium is determined endogenously, in a function which makes it proportional to the ratio of the foreign deficit to GDP. The "Asian Crisis" starts with a sudden rise in the proportionality parameter linking the risk premium to the ratio of the deficit to GDP. Contagion to other developing countries occurs when the proportionality factor in the 
risk-premium function of the $P O O R$ region rises as well.

The main actors in the model are households and firms who interact in commodity and factor markets. Government does not consume, save or invest. Instead, we assume that all government income is transferred directly to households, in the form of lump-sum transfers. The government budget is therefore presumed to be always balanced and there are no macroeconomic, fiscal-finance issues in this model.

\section{(a) Households and their consumption/savings}

In each region, the representative household owns labor, capital and all financial wealth, and allocates income to consumption and savings so as to maximize an intertemporal utility over an infinite horizon. The utility of the representative household in each region consists of the sum of the sequence of temporal utilities of aggregate consumption, discounted over an infinite time horizon. It is maximized in:

$\operatorname{Max} \sum_{t=0}^{\infty}\left(\frac{1}{1+\rho}\right)^{t} U\left(T C_{t}\right)$,

where $\rho$ is the positive rate of time preference; $U(\cdot)$ is instantaneous felicity at each time period. $T C_{t}$ is the instantaneous aggregateconsumption generated by final goods,

$T C_{t}=\prod_{i=1}^{4} C_{i t}^{b_{i}}$

where $0<b_{i}<1$, and $\Sigma b_{i}=1$.

The household in each region maximizes (1) subject to an intertemporal budget constraint

$\sum_{t=1}^{\infty} R_{t} P_{t}^{T C} \cdot T C_{t}=\omega_{1}$,

where $R_{t}=\prod_{s=1}^{t} 1 /\left(1+r_{s}\right) \quad$ represents the discount-factor and $r_{s}$ is the instantaneous interest rate. In (3), $P^{T C}$ is the consumer price index such that $P_{t}^{T C} T C_{t}=\sum_{i} P C_{i t} C_{i t}$ with $P C_{i t}$ denoting the (composite) price of commodity- $i$; and $\omega_{1}$ is the present value of the private household's aggregate financial wealth.

Households allocate their total income flows, from both financial and non-financial sources, between consumption and savings. The current budget constraint for the household is:

$$
\begin{aligned}
S A V_{t}= & {\left[W_{t} L_{t}+W k_{t} K_{t}+T I_{t}-r_{t} D_{t-1}\right] } \\
& -P_{t}^{T C} T C_{t},
\end{aligned}
$$

where $S A V$ is regional private savings; $W$ is the wage rate; $L$ the labor endowment; $T I$ is the lump-sum transfer of the government's tax revenues; $W k$ the capital rental rate, $K$ is the stock of physical capital-all in period $t$. The term $r_{t} D_{t-1}$ is the total interest payment on the outstanding foreign debt.

The Euler equation (derived from the firstorder condition of intertemporal utility maximization) implies that marginal utility ratios across any two adjacent periods satisfy the following condition:

$\frac{U_{t+1}^{\prime}}{U_{t}^{\prime}(1+\rho)}=\frac{P_{t}^{T C}}{P_{t}^{T C}\left(1+r_{t+1}\right)}$,

where $U_{t}^{\prime}$ is the derivative of the instantaneous utility function at time $t$ with respect to aggregate consumption $T C_{t}$. Eqn. (5) states that the marginal rate of substitution between consumption at time $t$ and $t+1$ must equal the ratio of the consumption price indices across the same time periods. Given the consumptionaggregation function (2), the price index of aggregate consumption, $P^{T C}$, is determined from the individual good prices according to,

$P_{t}^{T C}=\prod_{i=1}^{4}\left[\frac{P C_{t, i}}{b_{i}}\right]^{b}$.

\section{(b) Firms and investment}

The model distinguishes four production sectors: agriculture; consumer manufacturing; machinery and producer manufacturing; and services. Each sector produces a single output using labor, capital and intermediate goods as inputs. Labor and already-invested physical capital are not traded internationally. Valueadded in each sector is a Cobb-Douglas function of capital and labor. Intermediate inputuse is in fixed proportions.

The aggregate capital stock is managed by an independent investor (bank) who decides on the total investment level in each period and passes on all profits to households. The introduction of this bank-artifact serves to isolate the capital pricing and investment decisions of firms from the household-consumption and saving decisions. (As indicated below, foreign capital inflow makes up the difference between aggregate domestic savings and investment.) The 
investor chooses a time path of investment which maximizes his discounted profit over an infinite horizon:

$\operatorname{Max} \sum_{t=1}^{\infty} R_{t}\left(W k_{t} K_{t}-V_{t}\right)$

subject to a set of capital-accumulation constraints:

$K_{t+1}=(1-\delta) K_{t}+I_{t}$,

where $V I_{t}$ is the value of investment at $t ; I_{t}$ the new addition to physical capital; and $\delta$ is the (constant) capital-depreciation rate. We assume that the technology for producing capitalequipment exhibits constant returns to scale, there is no technical progress, and that there are no additional capital-installation costs beyond the cost of the final goods used in capital-goods production. Hence, when the level of investment is positive, in equilibrium, the value of each unit of capital equipment is uniquely determined by the prices of the investment goods. Thus, $V_{t}=P_{t}^{I} I_{t}$, where $P_{t}^{I}$ is the cost for each unit of $I_{t}$.

Under conditions of open, unregulated world capital markets, in equilibrium, the following no-arbitrage condition must also be satisfied:

$r_{t} P_{t-1}^{I}=W k_{t}-\delta P_{t}^{I}+P_{t}^{I}-P_{t-1}^{I}$.

This condition states that the total returns to capital must match the return to a perfectly substitutable asset of size $P_{t-1}^{I}$. The left-hand side of Eqn. (9) represents the returns from a perfectly substitutable asset of size $P_{t-1}^{I}$, and the right side of (9) is the total return from one unit of capital equipment, consisting of "dividends" from capital-ownership at each period, $W k_{t}$, minus the loss of value of capital equipment caused by depreciation, $\delta P_{t}^{I}$, plus a claim to an instantaneous capital gain (or loss) equal to $P_{t}^{I}-P_{t-1}^{I}$, if the cost of producing one unit of capital changes over time. The no-arbitrage condition of Eqn. (9) is used to determine the path of investment-demand in each region.

\section{(c) The foreign sector and foreign assets}

Commodities are differentiated in both demand and supply by their geographical origin. Regions are linked, on the demand side, by an Armingtonian composite-good system, and, on the supply side, by a constant-elasticity-oftransformation (CET) system. Domestically produced and foreign goods are regarded as imperfect substitutes in both trade and production, and assigned elasticities of substitution and transformation.

In each period, as investment and savings are independently determined in the model, the difference between the value of investment, $P_{t}^{I} I_{t}$, and the regional private savings, $S A V_{t}$, if positive, is the increase in debt of the home region borrowed from the other two foreign regions; i.e.,

$D_{t}-D_{t-1}=r_{t} D_{t-1}+F B_{t}$,

where $r_{t} D_{t-1}$ is the debt service payment and a positive $F B_{t}$ represents the foreign trade deficit.

\section{(d) Determination of the risk premium}

In view of the persistence of significant interest rate differentials across countries (see section 2), we use the following version of uncovered interest parity spelled out in real terms:

$r+\Delta P_{R}=r^{*}+\Delta P^{*}+\Delta \varepsilon_{R}+\pi_{R}$,

where $r$ is the domestic (region $R$ 's) interest rate; $r^{*}$ is the world interest rate in the international capital market; $\Delta P_{R}$ denotes changes in domestic (region $R$ 's) price level; $\Delta P^{*}$ denotes changes in world price level; $\Delta \epsilon_{R}$ is the change in nominal exchange rate; and $\pi_{R}$ is the risk premium which attaches to the domestic (region $R$ 's) capital market.

Transforming, we obtain:

$r-r^{*}=\left(\Delta P^{*}-\Delta P_{R}+\Delta \epsilon_{R}\right)+\pi_{R}$,

which decomposes interest-differentials into two components: deviations from relative purchasing power parity (the right-hand side term in parenthesis) and a real risk premium. Since we define the real exchange rate as the ratio of domestic to the foreign price level (see below) the terms in parenthesis vanish and we are left with: $r_{2}=r^{*}+\pi_{R}$.

We model the risk premium as a function of the ratio of the foreign deficit to GDP:

$\pi_{t}=P R\left(\frac{F B_{t}}{G D P_{t}}\right)$

Eqn. (11) is designed to capture the underlying disequilibrating characteristics of free international capital mobility: with a "positive" signal from the domestic economy, capital inflows are attracted into the domestic asset markets, causing a rapid accumulation of current-account deficits. The initial bonanza of debt-financed public (e.g., Turkey) or private (e.g., 
Mexico, Korea) spending escalates rapidly. This raises the risk-premium and generates severe fragility in the shallow financial markets of the home country. Eventually, the bubble bursts, and a series of severe and onerous adjustments are set in motion: very high real interest rates, sizable devaluations, and a severe retrenchment of aggregate demand. When the short-term "hot money" rushes out, the country is left broke, in a state of austerity and deprived of traditional tools of macroeconomic adjustment. This process generates an endogenous financial crisis analogous to that delineated by Minsky (1954) for the interaction of domestic business cycles with financial cycles. Elements of this vicious cycle are described in Kaminsky and Reinhart (1999), Diao, Li and Yeldan (1998), Dornbusch, Goldfajn and Valdés (1995), Velasco (1987), Diaz-Alejandro (1985), and more recently referred to as the Neftçi-Frenkel cycle in Taylor (1998) (following Neftçi, 1998; Frenkel, 1998).

\section{(e) Equilibrium}

Intratemporal equilibrium requires that during each time period, (i) in each region, demand for production factors equals their supply; (ii) in world commodity markets, aggregate demand for each sectoral good equals its total supply; (iii) and in the world's capital market, aggregate household savings equals zero when summed over all regions.

Intertemporal equilibria are described mainly by the difference Eqs. (5), (9) and (10). For the steady-state equilibrium path, the following constraints must also be satisfied for each region:

$r_{s s}+\delta=W k_{s s} / P_{s s}^{I}$,

$I_{s s}=\delta K_{s s}$

$F B_{s s}+r_{s s} D_{s s}=0$.

Eqn. (12) specifies that, in the steady state, the net marginal return of capital, normalized by the marginal value of capital, is constant and equal to the interest plus the depreciation rates; hence the marginal cost of investment and the capital rental rate are also constant. Eqn. (13) requires that aggregate investment just covers the depreciation of capital; hence, in the absence of labor growth and technical change, the capital/labor ratio also becomes constant. Eqn. (14) states that foreign debt holding is also constant. If a region holds foreign debt in the steady state (i.e., $D_{s s}$ is positive), then it has to have a trade surplus to pay the interest costs to foreigners on the outstanding debt (i.e., $F B_{s s}$ has to be negative). Moreover, in the steady state, as each region ceases to borrow from foreigners, domestic household savings ought to equal the value of aggregate capital investment.

\section{(f) The numeraire}

Central to any general equilibrium model is the specification of the numeraire, which we now make precise. In each region $K$, define the cost of living index at period $t$ by,

$P I N D E X_{K t}=\sum_{i} \Omega_{K i} P C_{K i t}$,

where $\Omega_{K i}$ is the weight of price $i$ (which is set equal to the share in consumption-demand of the $i$ th good). We choose the period 1 price index of the RICH region as the unit of value in our analysis. Therefore, all nominal values are expressed relative to PINDEX $X_{R I C H, 1}$.

Of particular interest is the concept of the real exchange rate, which we define as the relative cost of the common reference basket of goods among two regions, where the baskets' costs in the two regions are compared after conversion into the common numeraire. For two regions $A$ and $B$, with price levels $P I N D E X_{A, t}$ and PINDEX $X_{B, t}$, we say that region$A$ experiences a real appreciation (region- $B$, real depreciation) when the ratio of the respective price indexes, PINDEX $X_{A, t} / P I N D E X_{B, t}$, rises (see, e.g., Obstfeld \& Rogoff, 1996, chapter 4).

\section{GENERAL EQUILIBRIUM ANALYSIS OF THE ASIAN CRISIS}

What are the minimal conditions for generating a financial crisis? To answer this question we impose the same economic shock on the Asia region under two distinct scenarios, reflecting extremes in the degrees of external liberalization of the economy. Under the first scenario, neither trade nor capital markets are liberalized and the state retains its full panoply of policy instruments (experiment 1). Under the second scenario, both commodity markets and financial markets are completely liberalized; as a result, the state has becomes economically ineffective, as it has no policy instruments at its disposal (experiments 2 and 3 ). In this scenario 
we analyze the consequences for all regions with and without contagion from the Asia region to the region of least developed nations.

(a) Experiment 1: the developmental state: closed capital markets, pre-GATT

Under the first scenario, we examine quantitatively the dynamics of the so-called NeftçiFrenkel cycle (Taylor, 1998) in the context of Asian development. Starting from a reference path, we assume that the East Asian region experiences a parametric rise of $5 \%$ in the productivity of investment in physical capital. ${ }^{4}$ The positive productivity shock induces a rise in aggregate demand for investment in the region. Since in this experiment external finance is restricted, however, the burden of adjustment falls entirely on the domestic economy. In view of the region's history of active export promo- tion, we assume that the government responds to the need for increased foreign exchange and savings by introducing an export-subsidization program. We then let the model solve for the necessary adjustments in sectoral subsidy rates required to generate the requisite flow of foreign exchange earnings essential for financing the larger level of investment needed to take advantage of its greater productivity. ${ }^{5}$

The dynamics of adjustment are summarized in the EXP-1 columns of Table 1. The positive shock in the productivity of aggregate investment leads to a rise of investment expenditures by $18.4 \%$, prompting both increased domestic savings and more foreign exchange earnings through enhanced exports. Specifically, our numerical results indicate that the domestic saving rate is increased by three percentage points, from $29 \%$ to $32 \%$, as the marginal rate of substitution between current and future

Table 1. General equilibrium results (ratios of deviation)

\begin{tabular}{|c|c|c|c|c|c|c|}
\hline & \multicolumn{3}{|c|}{ EXP-1 (Relative to BASE Path) } & \multicolumn{3}{|c|}{ EXP-2 (Relative to Exp1) } \\
\hline & Period 1 & Period 5 & Period 15 & Period 1 & Period 5 & Period 15 \\
\hline \multicolumn{7}{|l|}{ Crisis hit Asian region, $C H A R$} \\
\hline Gross domestic product & 1.068 & 1.051 & 1.032 & 0.919 & 0.940 & 0.969 \\
\hline Consumption & 0.979 & 1.003 & 1.029 & 0.992 & 0.984 & 0.986 \\
\hline Investment & 1.184 & 1.146 & 1.105 & 0.928 & 0.948 & 0.954 \\
\hline Capital stock & $1.011^{\mathrm{a}}$ & 1.036 & 1.075 & $0.995^{\mathrm{b}}$ & 0.985 & 0.970 \\
\hline Exports & 1.077 & 1.052 & 1.026 & 0.938 & 0.964 & 0.992 \\
\hline Imports & 1.073 & 1.050 & 1.025 & 0.913 & 0.934 & 0.964 \\
\hline Foreign capital inflows & 1.000 & 1.000 & 1.000 & 0.373 & 0.304 & 0.384 \\
\hline Real exchange rate ${ }^{b}$ & 1.053 & 1.026 & 0.998 & 0.933 & 0.953 & 0.982 \\
\hline \multicolumn{7}{|l|}{ Output supply } \\
\hline Agriculture & 0.982 & 1.004 & 1.027 & 1.002 & 0.993 & 0.990 \\
\hline Consumer manufacturing & 1.070 & 1.061 & 1.053 & 0.937 & 0.956 & 0.977 \\
\hline Producer manufacturing & 1.086 & 1.069 & 1.052 & 0.944 & 0.964 & 0.976 \\
\hline \multirow[t]{3}{*}{ Services } & 0.969 & 1.000 & 1.032 & 1.032 & 1.009 & 0.987 \\
\hline & \multicolumn{3}{|c|}{ EXP-3 (Relative to BASE Path) } & & & \\
\hline & Period 1 & Period 5 & Period 15 & & & \\
\hline \multicolumn{7}{|l|}{ Underdeveloped Region, POOR } \\
\hline Gross domestic product & 0.922 & 0.922 & 0.932 & & & \\
\hline Consumption & 0.971 & 0.970 & 0.984 & & & \\
\hline Investment & 0.921 & 0.900 & 0.807 & & & \\
\hline Capital stock & $0.996^{\mathrm{a}}$ & 0.985 & 0.937 & & & \\
\hline Exports & 1.032 & 1.031 & 1.016 & & & \\
\hline Imports & 0.885 & 0.885 & 0.899 & & & \\
\hline Foreign capital inflows & 0.009 & 0.039 & 0.232 & & & \\
\hline Real exchange rate ${ }^{b}$ & 0.925 & 0.928 & 0.955 & & & \\
\hline \multicolumn{7}{|l|}{ Output supply } \\
\hline Agriculture & 0.994 & 0.991 & 0.992 & & & \\
\hline Consumer manufacturing & 1.036 & 1.026 & 0.990 & & & \\
\hline Producer manufacturing & 0.993 & 0.977 & 0.912 & & & \\
\hline Services & 0.992 & 0.984 & 0.956 & & & \\
\hline
\end{tabular}

\footnotetext{
${ }^{\text {a }}$ Period 2.

${ }^{\mathrm{b}}$ Ratio of the Consumer Price Index to the Consumer Price Index of the RICH. An increase indicates appreciation.
} 
consumption falls due to the higher productivity of savings. The impact equilibrium rate of export subsidy rises by five percentage points. The region meets the increased import demand (by 7.3\% upon impact) through increased export earnings, and the overall foreign balance is maintained constant, at its initial base-path level.

The real exchange rate appreciates, due to the nature of the shock. Positive gains in GDP lead to a rise in the cost of the domestic consumption basket relative to its world-market price. Yet, the government does not allow the appreciation of the real exchange rate to deteriorate the competitiveness of exports; it counteracts this effect by its active subsidization of exports. ${ }^{6}$ The gross domestic product increases by $6.8 \%$ over its base path, and, as households respond to the higher returns on savings by substituting future consumption for current consumption. Domestic savings rise to finance the increased pace of capital accumulation. This enables the aggregate capital stock to be $7.5 \%$ larger by period 15 . Thus, the positive productivity shock and active government response, permitted by the absence of restraints on commercial policy and closed financial markets, result in a substantial net benefit to the economy.

(b) Experiment 2: the impotent state: open capital markets, post-GATT

Now consider the same productivity shock under a post-GATT regime, which abolishes export subsidies, and with a deregulated capital account. With unregulated, open capital markets, the productivity gains stimulate foreign capital inflows. In addition, rational domestic agents substitute consumption intertemporally, reducing today's consumption in favor of greater future consumption. Current consumption expenditures fall, allowing domestic savings to rise to help finance increased investment expenditures. Up to here the effects on the economy are beneficial. There is an investment boom, and an increase in the rate of economic growth typical of the first phase of financial crises in an open economy.

The increased foreign capital inflow, however, inevitably leads to an appreciation of the domestic currency in real terms, resulting in a loss of international competitiveness of the country's exports. This leads to a contraction of exports relative to what they would have been without the appreciation. The foreign deficit widens as a result. This rise in deficit is interpreted by international financial markets as a signal of increased financial fragility, typical of the second phase of a financial crisis, in which a boom carries with it the seeds of its own destruction due to greater financial risk.

Our numerical simulations indicate that, by comparison with the initial reference path, the foreign deficit widens threefold upon impact to reach $6.3 \%$ of GDP. The percentage deficit remains above $4 \%$ until the end of the first five years of adjustment, and does not converge back to its initial level until year 10 (see Figure 1). The international financial markets respond

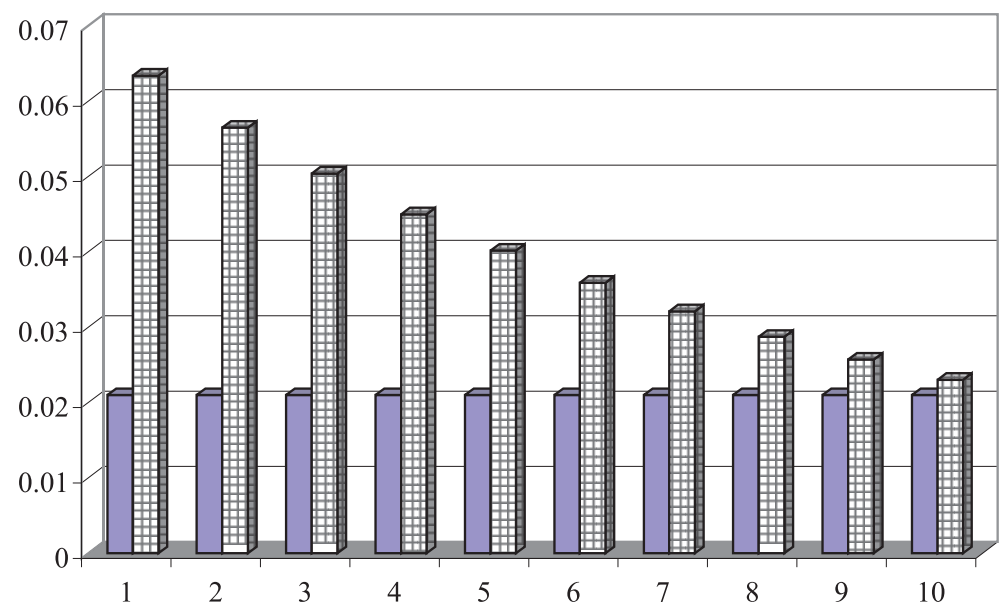

Figure 1. Ratio of foreign deficit to the GDP under unregulated capital inflows. 
to this indicator of the boom's financial fragility by withdrawing capital from the economy abruptly, in a herd-psychology induced selffulfilling panic. Net foreign capital inflows drop to $63 \%$ of their base value.

We model the financial fragility of the East Asian region with the aid of the risk generator function (Eqn. (11) above) in which the risk premium rises (falls) in proportion to the ratio of foreign deficit to GDP. We simulate the panic elements of the crisis by an abrupt, parametric, 10-fold rise in the risk parameter $P R$ in Eqn. (11). This has the effect of increasing the domestic rate of interest over the world interest rate substantially and of choking off foreign lending. Consequently, investment demand drops abruptly, and GDP contracts despite a real devaluation.

Observe that, in this formulation of financial fragility, the "deterioration" of macro fundamentals which leads to an increase in risk premium, reflects neither public mismanagement, nor deficiencies in banking or corporate governance, nor market imperfections or moral hazard, but is a direct consequence of the inherent characteristics of well-functioning, integrated global capital markets. Indeed, as many contributors to this special issue claim, one might say that the financial markets are too perfect. They permit herd behavior leading to financial panic and crisis.

We summarize the response of the region's main macroeconomic aggregates to the crisis and the contagion effects in the world financial and commodity markets under the EXP-2 columns of Table 1 . We present our numerical results for this experiment as percentages of their values in EXP-1, the environment with regulated capital flows. Our results indicate that, by comparison to EXP-1, gross domestic product in the Asian region contracts by $8.2 \%$ upon impact, and remains trapped in a 3.1\% lower long-run equilibrium growth path. In Figure 2, we depict the extent of cumulative losses of GDP in relation to their theoretically expected, potential level. Such losses in potential GDP escalate rapidly and reach $25 \%$ by period 5 , and $70 \%$ by period 15 .

The major macro aggregates of the postcrisis adjustment path of the East Asia region are further portrayed in Figure 3. The sudden increase in the risk premium leads to a divergence between the domestic (regional) interest rate and the world interest rate. The resulting increase in the regional rate of interest chokes off investment demand (by $7.2 \%$ upon impact, and by $4.6 \%$ as of period 15), and reduces private consumption expenditures, but only very slightly. The contraction of investment leads directly to a slowdown in capital accumulation and decline in real output. The deceleration in the rate of growth of the capital stock deepens progressively, and by period 15, is 3.0\% lower than in EXP-1 (Figure 3). Thus, the experiment indicates that the postcrisis adjustment of the Asian region involves substantial contraction of real output together with sluggish accumulation patterns.

Had it not been for the increase in the economy's risk premium (which is, alas, inevitable) and for the unregulated nature of capital flows, the contraction in investment and output

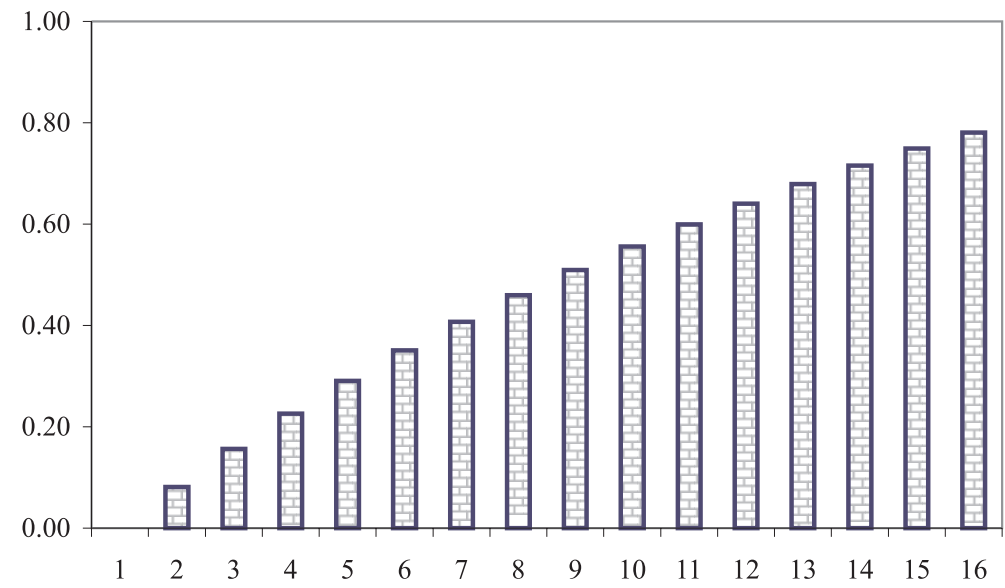

Figure 2. Cumulative loss of post-crisis GDP compared to intertemporal equilibrium of EXP-1. 


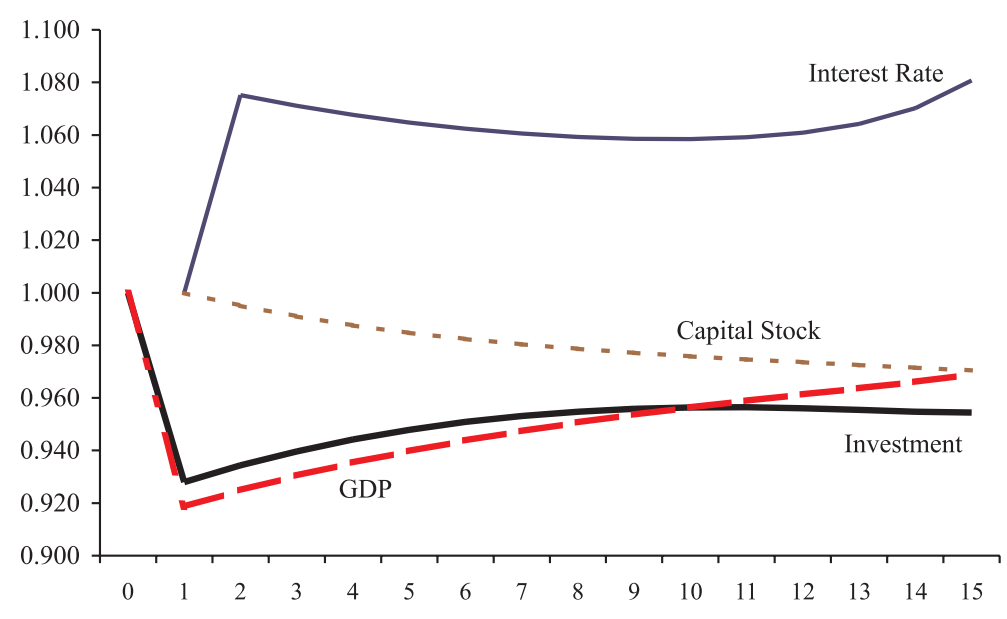

Figure 3. Macro aggregates under post-crisis Asia.

would have resulted in a self-regulating economic cycle and a soft landing even without government policy intervention. With normal marginal efficiency of investment curves, the expansion of the capital stock which preceded the crisis would have eventually led to a drop in the marginal productivity of investment, triggering a decline in the rate of growth of further investment expenditures, and a narrowing in the savings-investment gap. Inflows of foreign capital would then have been reduced, the foreign deficit fallen and the exchange rate devalued. The economy would have been running a trade surplus to pay for the interest costs of the initial debt accumulated. And intertemporal optimizers, who initially raised their savings in response to the increase in the rate of return of invested saving, would now reduce their savings and enjoy a higher level of consumption into the indefinite future. In the very long run, the economy would have approached a new, lower, steady-state equilibrium.

Instead, however, rather than the smooth adjustments forecast by textbook models of consumption smoothing and intertemporal optimization, the openness of capital markets and increase in regional risk premium allowed the disequilibria in fundamentals to escalate. Massive movements of capital amplified the traditional adjustment process so much that the economy overshot and was unable to return to its pre-shock, long-run equilibrium growth path. In the case of our experiment, the massive movements of capital wound up inducing an escalation in risk-premium which converted a positive shock into a financial and real crisis. The real negative shock generated by the large capital outflows far exceeded that required for adjustment and persisted into the long run. In the words of Blecker (1998, p. 30) "capital mobility seems to introduce what might be called 'nonlinearities' into the intertemporal adjustment process... causing current account imbalances to persist or to grow more severe."

(c) Experiment 3: the impotent state: open capital markets, post-GATT, contagion to other developing countries

In this experiment, we study the effects of contagion to other developing countries. Technically, we model the contagion cycle by repeating Experiment 2, but with increased risk premium for the POOR region as well. Thus, we impose increased fragility in global capital markets.

We find that the contagion cycle is more contractionary for the rest of the developing world than was the financial crisis for the East Asian region. This is partly due to the fact that the $P O O R$ region's financial crisis did not result from an initial increase in the productivity of its capital, but was simply the result of irrational contagion from East Asia. Even though the pre-crisis, precontagion fundamentals of the region remained unchanged, foreign capital inflows into the region collapse. The POOR region's GDP declines by as much 7.8\% (EXP-3 path of Table 1) upon impact and remains $6.8 \%$ below its base level in year 15. Fixed investment demand slumps by $7.9 \%$ at impact (Figure 4). 


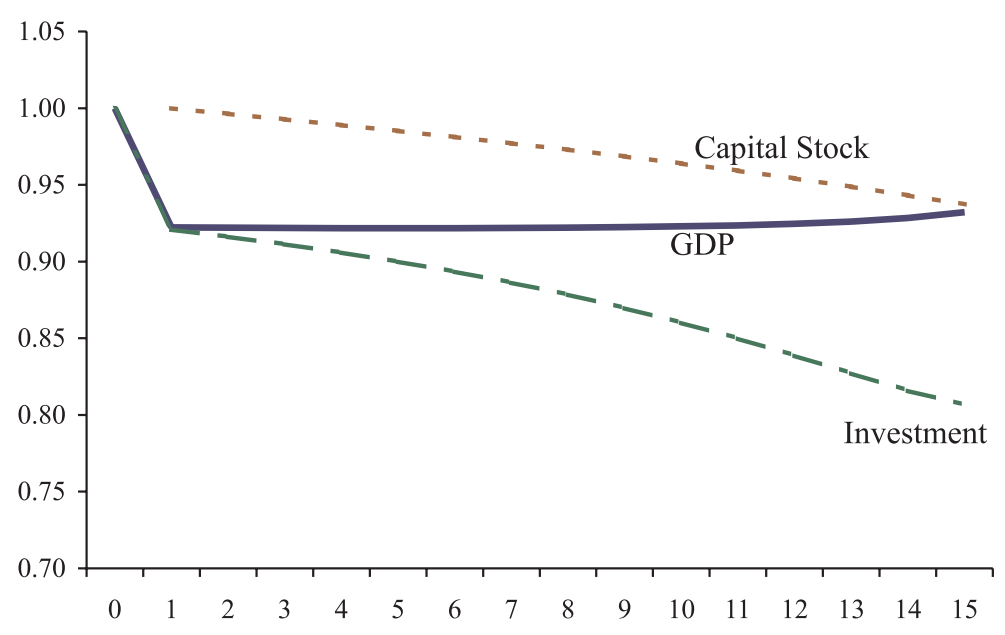

Figure 4. Macro aggregates in the underdeveloped region under contagion of global crisis.

The long-term effects of the crisis are felt more severely over time as the deceleration of the rate of capital accumulation deepens; it reaches a $20 \%$ lower level by year 15 . The impact on the POOR, contagion-hit region, which was completely blameless, is thus permanent.

A counterpart of all these adjustments is the behavior of the (real) exchange rate. Our numerical results show a real depreciation of the currency in both postcrisis Asia and postcontagion underdeveloped region. But the magnitude of the real depreciation in the model was much smaller than it had been in the actual Asian crisis. When the capital flows are drastically reduced (see Figure 5) domestic curren- cies suffer a real depreciation of only $7.1 \%$ as compared to the $50 \%$ depreciation that occurred in practice in the Asian region. One can conjecture that the lower depreciation in the model is due to the fact that the model economy does not undergo a banking crisis at the same time as it experiences a financial crisis. While domestic interest rate escalate, there is no scramble for liquidity in the model, and no liquidation of assets to obtain foreing exchange. In addition, the model has flexible exchange rates, so that the adjustment to the shock imparted by the reversal of capital flows can be more gradual. In our formulation, exchange rate declines do not, in and of them-

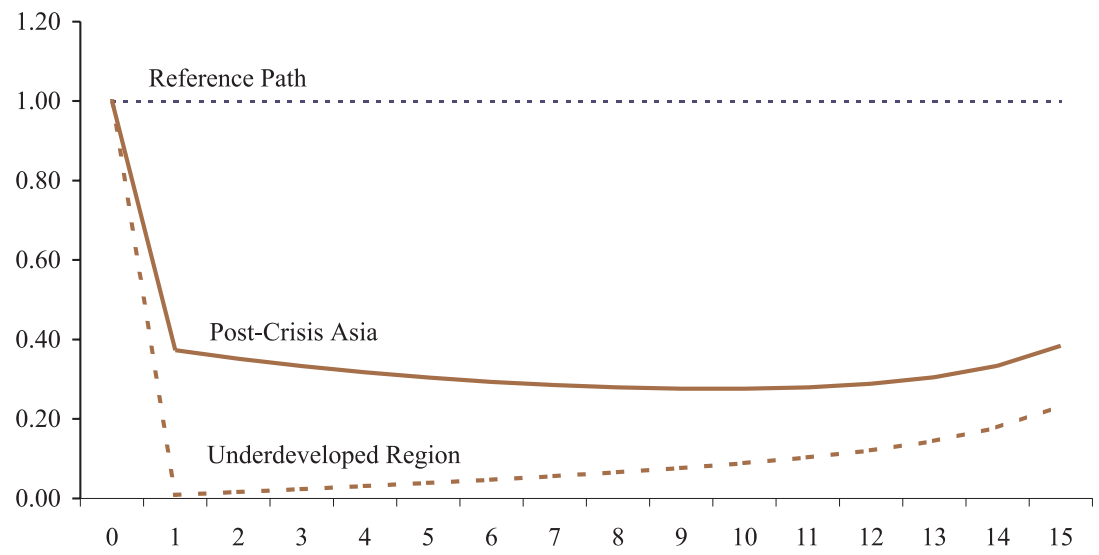

Figure 5. Inflow of foreign capital in post-crisis Asia and the underdeveloped region after contagion. 


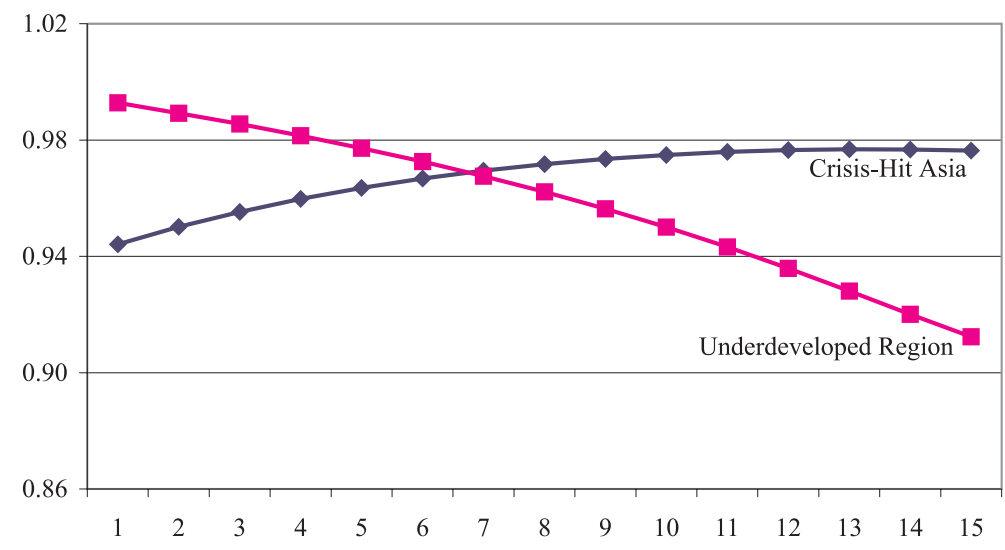

Figure 6. Producer manufacturing real output following contagion of the Asian crisis.

selves, affect the risk premium and cause increased capital outflows and greater domestic interest rates.

Perhaps the most pernicious long-run effect of the Asian crisis on their development consist of the nature of the structural change that it induces in real output supplies, capital accumulation and pattern of economic growth. Upon impact, we observe a drop in the gross output of consumer and producer manufacturing industries and a rise in agriculture and services. In the short run, this effect is due purely to relative price movements. In the medium term, the decline in manufacturing results from the contraction of aggregate investment demand, which leads to a deflationary environment in which demand for producer-manufacturing falls in a sustained fashion. (Figure 6). As patterns of capital accumulation diverge from their base trajectory, producer-manufacturing output-growth slows down and a process of deindustrialization develops. This is arguably the most detrimental long-run consequence of financial crises for economic development.

\section{POLICY DISCUSSION AND CONCLUDING COMMENTS}

Experiments 1 and 2 describe how a financial crisis arises when capital markets are open and does not arise when capital markets are closed and the government retains its full arsenal of instruments for policy intervention. By generating the financial crisis within a set of globally interacting world regions embedded in a CGE model, we stripped away a large number of features of reality that are often blamed for giving rise to financial crises. The model in which the opening up of capital markets breeds a financial crisis is entirely neoclassical, with fully functioning commodity and financial markets, in which both factor movements and trade adjust flexibly to market conditions. The actors are completely rational and forward looking. Exchange rates are flexible. Financial markets are not plagued by moral hazard or incomplete information. The banking system is not underdeveloped or underregulated. In the model banks intermediate perfectly between savings and investment, allocating resources to their most profitable uses. Financial transactions occur at arm's-length, and are not characterized by crony capitalism. Corruption does not play a role in the interaction of the private sector of the model economy with either the government or the financial system. There are no macroeconomic excesses, as the government budget is always balanced. There is also no IMF.

The crisis is generated endogenously by a single trigger: an increase in the risk premium that is fully justified by the mounting level of foreign indebtedness and by the increasing size of the current account deficit in the periods preceding the crisis. In turn, the rising deficit and foreign indebtedness are themselves due to large inflows of foreign capital fueled by expectations of high economic growth triggered, in our model, by increases in domestic productivity. When expectations turn, the risk premium soars, precipitating large decreases in short-term capital inflows and giving rise to a full-blown financial-cum-real crisis. 
From a policy point of view, the very starkness of the picture of the financial crisis painted by our simulations implies that many of the remedies suggested for avoiding future financial crises will do no such thing. These include: financial sector reform; better information; the creation of a new international institution to supervise international financial transactions and operate as a lender of last resort; cleaning up corruption in lending; getting the government out of the targeting business; and improving the governance of the corporate sector. Of course, these reforms may well reduce the magnitude of financial crises once they arise and may well contribute to the institutional maturity of the country. Indeed, while, in our model economy, the growth rate declines resulting from the crisis are of roughly the right order of magnitude, the collapse in asset values and exchange rates devised by the model is considerably too modest. In addition, the suggested institutional reforms may well be desirable in and of themselves, as they are likely to contribute to the institutional maturation of the developing country.

It is nevertheless significant that, in an "economy" in which all of the reforms listed above (other than a new international financial institution), are already in place, the declines in growth rates are of roughly the right orders of magnitude. The only thing our model required for a crisis to develop was short-term financial markets open to international financial flows and the herd-behavior induced by common perceptions of future prospects that are typical of all expectation-based markets. In this vein, our analytical model suggests that the fundamental remedy for financial crises lies in regulating short-term international flows. Our experiments thus highlight the now classic dictum due to Keynes, Aabove all, let finance be primarily "national."

Avoidance of a financial crisis is not the only reason for preferring a global economy with more regulated short-term financial flows to one in which international capital markets are completely open. The main reason may well be that unregulated short-term capital markets rob national economies of all the indirect, untargeted policy instruments they retain in a post-GATT world. These instruments are needed not only for macroeconomic purposes but also for the promotion of industrialization and development.

When fully open capital markets replace the combination of closed short-term capital markets and regulated flows of foreign investment, governments become unable to employ their traditional policy instruments (interest rates, government expenditures and exchange rates) unilaterally, for fear of triggering a financial crisis: Raising interest rates above world markets induces a large foreign capital inflow, setting the stage for a subsequent financial crisis; fixing them below world markets, precipitates a large foreign capital outflow, generating the crisis immediately. Similarly, setting exchange rates above equilibrium levels leads to a current account deficit, raising risk premiums and domestic interest rates, and leading to a subsequent crisis; fixing exchange rates below equilibrium stimulates capital flight and investment abroad in anticipation of further devaluations, producing the crisis outright. Finally, running a budget deficit to stimulate growth or provide social programs more generous than the international norm, causes capital outflows. Flexible exchange rates, have two opposite effects: on the one hand, they enable less abrupt adjustments and therefore may well lead to a softer landing. On the other hand, flexible exchange rates may well amplify the effects of international capital flows by allowing speculation on foreign exchange markets that are excessively large; excessively liquid; excessively volatile; too imperfectly informed; and too subject to herd psychology.

In the words of the UNCTAD's (1998) Trade and Development Report,

the ascendancy of finance over industry together with the globalization of finance have become underlying sources of instability and unpredictability in the world economy. (...) In particular, financial deregulation and capital account liberalization appear to be the best predictor of crises in developing countries (pp. v and $55)$.

Almost all recent episodes of financial-cumcurrency instability indicate that the observed sharp swings in capital flows are mostly a reflection of large divergences between domestic financial conditions and those in the rest of the world. These divergences may well have been required to implement national objectives. Reversals of capital flows are often associated with deterioration of the macroeconomic fundamentals in the domestic country. However, "such deterioration often results from the effects of capital inflows themselves as well as from external developments, rather than from shifts in domestic macroeconomic policies" (UNCTAD, 1998, p. 56). 


\section{NOTES}

1. Balkan and Yeldan (1998) report, for instance, that prior to its financial crash in 1994, the speculative attack on the Turkish asset markets led to an annual gross volume of $\$ 130$ billions (about two-thirds of the country's GDP) while the net foreign capital inflows stood around only $\$ 5$ billions.

2. For a textbook treatment of neoclassical intertemporal general equilibrium, see Blanchard and Fischer (1989) or Obstfeld and Rogoff (1996).

3. Throughout the analytical section of the paper we use the terms "domestic" and "regional" interchangeably.
4. Technically this would mean a drop in the cost of investment $P$ in Eqn. (9).

5. The subsidies are modeled by introducing a slack variable for export subsidy adjustments to serve as the shadow price of the fixed foreign balance-BFBt for all $t$.

6. A similar, but less differentiated effect could have been accomplished through devaluation.

\section{REFERENCES}

Balkan, E., \& Yeldan, E. (1998). Financial liberalization in developing countries: the Turkish experience. In: R. Medhora, \& J. Fanelli, Financial liberalization in developing countries. New York: McMillan.

Blanchard, O. J., \& Fischer, S. (1989). Lectures in macroeconomics. Cambridge, MA: The MIT Press.

Blecker, R. A. (1998). International capital mobility, macroeconomic imbalances, and the risk of global contraction. Center for Policy Analysis, Working Paper Series III, No. 5, New School for Social Research, New York, June.

Diao, X., Li, W., \& Yeldan, E. (1998). Challenges and choices in post-crisis East Asia: simulations of investment policy reform in an intertemporal, global model. Department of Economics Discussion Paper No: 98 16, Bilkent University, Ankara.

Diaz-Alejandro, C. F. (1985). Good-bye financial repression, hello financial crash. Journal of Development Economics, 19, 1-24.

Dornbsuch, R., Godfajn, I., \& Valdés, R. (1995). Currency crises and collapses. Brookings Papers on Economic Activity 2 (June), 219-270.

Eatwell, J. (1996). International capital liberalization: the record. Center for Policy Analysis, Working Paper Series I, No. 1, New School for Social Research, New York, August.

Frankel, J. A. (1991).Quantifying international capital mobility in the 1980s. In: D. Bernheim, \& J. Shoven, National savings and economic performance. Chicago: The University of Chicago Press.

Frankel, J. (1992). Measuring international capital mobility: a review. American Economic Review.

Frankel, J. (1993). International financial integration: relations between interest rates and exchange rates. In D. Das, International finance: contemporary issues. London: Routledge.
Frenkel, R. (1998). Capital market liberalization and economic performance in Latin America. Center for Policy Analysis, Working Paper Series III, No. 1, New School for Social Research, New York, May.

Halwood, C. P., \& MacDonals, R. (1994). International money and finance. London: Blackwell.

Kaminsky, G., \& Reinhart, C. (1999). The twin crises: The causes of banking and balance-of-payments problems. American Economic Review, 89 (3), 473500.

Marston, R. C. (1997). Tests of three parity conditions: distinguishing risk premia and systematic forecast errors. Journal of International Money and Finance 16 (2), 285-303.

Minsky, H. P. (1954). Induced investment and business cycles. Ph.D. Dissertation, Harvard University, Cambridge, MA.

Neftçi, S. (1998). FX short positions, balance sheets, and financial turbulence: an interpretation of the Asian financial crisis. Center for Policy Analysis, Working Paper Series III, No. 4, New School for Social Research, New York, June.

Obstfeld, M., \& Rogoff, K. (1996). Foundations of international macroeconomics. Cambridge, MA: The MIT Press.

Taylor, L. (1998). Lax public sector, destabilizing private sector: origins of capital market crises. Center for Policy Analysis, Working Paper Series III, No. 6, New School for Social Research, New York, July.

UNCTAD (1998). Trade and development report. UNCTAD, Geneva.

Velasco, A. (1987). Financial crises and balance of payments crises: a simple model of southern cone experience. Journal of Development Economics, 27, 263-283. 